Ann. Zootech., 1982, 31 (4), 483-488

NOTE

\title{
The effects of the gut microflora on the digestibility of starch and proteins in young chicks
}

\author{
R. KUSSAIBATI, J. GUILLAUME et B. LECLERCQ \\ I.N.R.A., Station de Recherches avicoles \\ Centre de Recherches de Tours \\ Nouzilly, F 37380 Monnaie
}

\begin{abstract}
Summary
The effects of the gut microflora on the digestibility of starch and proteins of a diet composed mainly of ground maize and soybean meal, and containing 150 and $240 \mathrm{~g} / \mathrm{kg}$ of animal fat and total protein respectively, were studied in germ-free (GF) and conventional (CV) young chicks. A nutritional balance was conducted to assess the digestibility coefficients. Starch of feed and excreta were estimated after being hydrolyzed to glucose by the glucamylase enzyme. Excreted proteins were precipitated by lead acetate to eliminate uric acid before the determination of nitrogen by Kjeldahl's method. The results demonstrated that the digestibility of starch was not affected by the gut microflora. On the contrary, the apparent digestibility of proteins was significantly $(\mathrm{p}<0.01)$ improved in GF chicks.
\end{abstract}

\section{Introduction}

KusSaIBATI et al. (1982) demonstrated that apparent or true metabolizable energy values of a diet, composed mainly of ground maize and soybean meal and containing $150 \mathrm{~g} / \mathrm{kg}$ of animal fat and $240 \mathrm{~g} / \mathrm{kg}$ of total proteins $(\mathrm{N} \times 6.25)$, were slightly higher in germ-free (GF) chicks than in their conventional (CV) counterparts. This phenomenon was explained by a better apparent digestibility of fats, especially saturated fatty acids, palmitic and stearic.

The present work aims to study the effects of gut microflora on the digestibility of starch and proteins. In addition, the endogenous nitrogen and fat losses have been estimated in both GF and CV chicks in order to complete the results of our previous investigation. 


\section{Material and methods}

Details of experimental procedures have been described previously (Kussaibatr et al., 1982). In addition, starch and proteins were assayed in samples of feed and excreta in order to estimate their digestibility coefficients.

Starch of feed and excreta were hydrolysed by glucamylase (Amyloglucosidase, Merck) into glucose according to the method described in A.F.N.O.R. (1966). Released glucose was quantitatively estimated by a glucose analyser (Beckman BGA 2). Proteins of the excreta were estimated after being precipitated by lead acetate according to the method of TÉRPSTRA \& DE HART (1974), in order to eliminate uric acid which is considered as the main nitrogen component of the urine (HILL \& ANDERson, 1958). Feed and precipitated excreta proteins were determined by Kjeldahl's method $(\mathrm{N} \times 6.25)$.

\section{Results and discussion}

Germ-free chicks gained slightly but significantly $(P<0.05)$ more weight than their conventional counterparts (final body weight 160 and $142 \mathrm{~g} / \mathrm{bird}$ ). However, no significant difference in feed intake was detected (feed intake 26.9 and $27.5 \mathrm{~g} /$ day/bird for germ-free and conventional chicks respectively). Thus, the improvement in final body weight could be only explained by the observed increase in the metabolisable energy values which are directly related to the digestibility of energetic nutrients : lipids, starch and proteins. This observation was partially explained by an increase in the apparent digestibility of lipids, especially saturated fatty acids, when the gut microflora were absent (Kussaibati et al., 1982).

Results concerning the coefficients of digestibility of starch and proteins are shown in table 1. It was found that maize starch digestibility was generally low (equal or less than 94 p. 100), although the same diet fed to a different strain of $\mathrm{CV}$ chicks yielded coefficients higher than 98 p. 100 (Kussaibati, Leclerce \& GuilLAUME, 1982). However the gut microflora had no significant effect on the digestibility of this nutrient, although the coefficients were, numerically, slightly higher in GF chicks. These findings confirm the results of BeWa, Charlet-Lery \& Szylit (1979) who demonstrated that the gut microflora had no effect on starch digestibility irrespective of the type of starch used (starch of different tropical tubercles). Although Ivorec-Szylit, Raibaud \& Schellenberg (1973) and Champ, SzYlit \& Gallant (1981) have demonstrated and visualized the breakdown of starch by the gut microflora in chickens, particularly in the crop, it seems unlikely that this breakdown has any quantitative importance on the overall digestion and absorption of starch, in view of the report by LEPKOVSKY et al. (1964) that there are no differences between the amylase activities of GF and CV chicks fed a natural diet.

Coefficients of apparent protein digestibility were significantly higher $(\mathbf{P}<0.01)$ in GF than in CV chicks. These results are in contrast with those of MILLER (1967), Erbersdobler \& Riedel (1972) and Salter \& Fulford (1974) who found that gut microflora had no effect on protein and amino acid digestibility in chicken. However 
the results of BEWA et al. (1978) demonstrated that the effect of gut microflora on protein retention depended substantially on the composition of the diet : type of starch, proportion of protein, and presence or absence of soluble carbohydrates. Furthermore, SzyliT \& CHARLET (1981) concluded that the gut microflora had a depressive effect on protein retention, especially when low protein diets were used.

\section{TABLE 1}

Coefficients of the digestibility of lipids,

starch and proteins in germ-free and conventional chicks (p. 100)

(one value was obtained from a group of 10 chicks).

Coefficients de l'utilisation digestive des lipides,

de l'amidon et des protéines chez les poussins axéniques et holoxéniques (p. 100)

(une seule valeur est obtenue à partir d'un groupe de 10 poussins).

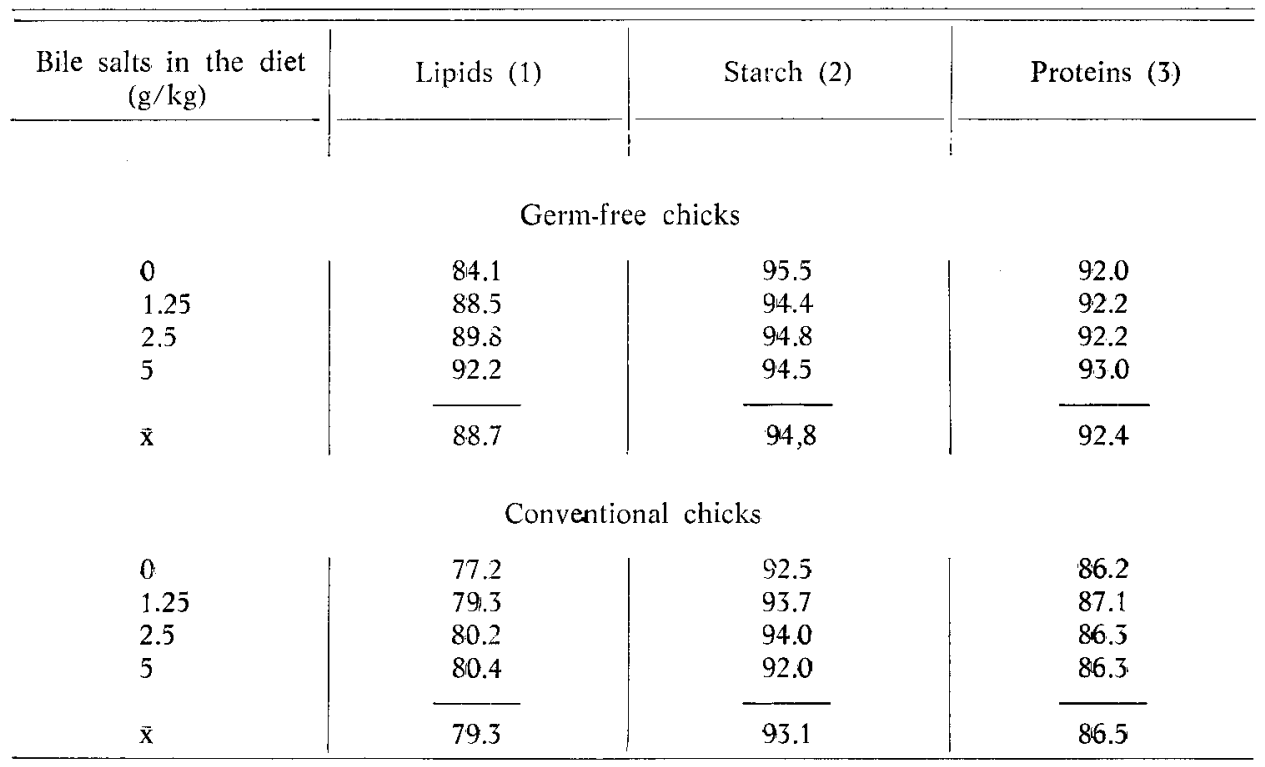

(1) Values within a column (effect of different concentrations of bile salts) are not significantly different, but between columns (effect of the gut microflora) are significantly different $(\mathbf{P}<0.01)$.

(2) Values within a column and between columns are not significantly different.

(3) Values within a column are not significantly different, but between columns are significantly different $(\mathbf{P}<0.01)$.

These contradictory results demonstrate the extent to which the effect of the gut microflora on nitrogen utilisation in the chicken is related to the composition of the diet. However, the improvement of protein digestibility in GF chickens could be partially explained by an increase in endogenous nitrogen losses in CV chicks (tabl. 2) 
which may due to a faster cell renewal in such animals (Rolls, Turvey \& CoATEs, 1978) and to the mass of the excreted microflora which represent a substantial proportion of amino acids in poultry excreta (PARSONS et al., 1982). It is also possible that the increase in fat digestibility in GF chicks brought about a parallel improvement in protein digestibility. This interaction between fat and protein digestibility has recently been demonstrated by KusSaIBati, LeClerce \& Guillaume (1982) in young CV chicks. Finally, the increase of intestinal absorption in GF animals may exercise an important role in the improvement of protein digestibility, in view of the suggestion that the decreased lamina propria tissue and cellular tissue associated with the defense mechanism renders the mucosal surface of the GF intestine more efficient for absorption (GORDON, 1960).

TABLE 2

Endogenous excreta ( $g$ dry matter $/ 24$ h starvation), nitrogen and lipids excretions $(\mathrm{g} / \mathrm{kg}$ endogenous dry matter excreta) in germ-free and conventional chicks

(one value was obtained from a group of 10 chicks).

Excréta d'origine endogène ( $g$ matière sèche/24 h de jeûne), excrétion d'azote et de lipides ( $\mathrm{g} / \mathrm{kg}$ de matière sèche d'excréta d'origine endogène) chez les poussins axéniques et holoxéniques

(une seule valeur est obtenue à partir d'un groupe de 10 poussins).

\begin{tabular}{|c|c|c|}
\hline $\begin{array}{l}\text { Bile salts in the diet } \\
\qquad(\mathrm{g} / \mathrm{kg})\end{array}$ & Germ-free & Conventional \\
\hline \multicolumn{3}{|c|}{ Endogenous excreta (1) (dry matter) } \\
\hline $\begin{array}{l}0 \\
1.25 \\
2.5 \\
5\end{array}$ & $\begin{array}{l}9.9 \\
9.4 \\
8.9 \\
8.8\end{array}$ & $\begin{array}{r}9.2 \\
10.6 \\
9.3 \\
8.0\end{array}$ \\
\hline \multicolumn{3}{|c|}{ Endogenous nitrogen (2) (faecal + urinary) } \\
\hline $\begin{array}{l}0 \\
1.25 \\
2.5 \\
5\end{array}$ & $\begin{array}{l}145 \\
165 \\
154 \\
167\end{array}$ & $\begin{array}{l}197 \\
193 \\
191 \\
187\end{array}$ \\
\hline \multicolumn{3}{|c|}{ Endogenous lipids (3) } \\
\hline $\begin{array}{l}0 \\
1.25 \\
2.5 \\
5\end{array}$ & $\begin{array}{l}39 \\
26 \\
22 \\
20\end{array}$ & $\begin{array}{l}39 \\
36 \\
30 \\
32\end{array}$ \\
\hline
\end{tabular}

(1) Values within a column (effect of different concentrations of bile salts) and between columns (effect of the gut microflora) are not significantly different.

(2) Values within a column are not significantly different but between columns are significantly different $(P<0.05)$.

(3) Values within and between columns are not significantly different. 
It was also found that the addition of different concentrations of bile salts to the diet affected neither the digestibility of maize starch nor that of proteins.

Freeze dried endogenous excreta, collected during a 24 hour starvation period (tabl. 2) were quantitatively similar in both GF and CV chicks. The same results were observed for endogenous lipid excretion, but the addition of different levels of bile salts to the diet before starvation decreased endogenous lipid excretion in GF chicks. Because the excretion and absorption of bile acids are continuous processes and only a small quantity of these acids fail to be absorbed (EASTwood, 1973), the increase in bile salt availability in the gut of GF chicks, due to the absence of the gut microflora and the addition of bile salts, may lead to an increase in endogenous lipid reabsorption.

In conclusion, the improvement of final body weight and metabolisable energy values in GF chicks were due not only to the increase in the apparent digestibility of fats, especially saturated fatty acids (Kussaibati et al., 1982) but also to the improvement in the apparent protein digestibility. It was also noted that the digestibiliy of maize starch used in the experimental diet was not affected by the gut microflora.

Accepted for publication in October 1982.

\section{Résumé \\ Effets de la microflore du tube digestif sur l'utilisation digestive de l'amidon et des protéines chez le poussin en croissance}

Les effets de la microflore du tube digestif sur la digestibilité de l'amidon et des protéines sont étudiés chez des poussins axéniques et holoxéniques. Le régime alimentaire est composé essentiellement de maïs, de tourteau de soja et de graisse animale (15 p. 100 de graisse animale et 24 p. 100 de protéines totales). Un bilan nutritionnel est effectué en vue d'estimer les coefficients d'utilisation digestive. L'amidon du régime et des excreta est dosé après avoir été hydrolysé en glucose par la glucamylase. Les protéines excrétées sont précipitées par l'acétate de plomb pour éliminer l'acide urique. Ensuite, l'azote est dosé par la méthode de Kjeldahl. Les résultats démontrent que les coefficients d'utilisation digestive de l'amidon ne sont pas influencés par la microflore. Par contre, ceux de protéines sont significativement $(\mathrm{p}<0,01)$ améliorés en l'absence de la microflore du tube digestif.

\section{References}

A.F.N.O.R., 1966. Dosage de l'amidon. Produits de l'agriculture, amidons et fécules. VO3 - 606, 1-6.

Bewa H., Charlet G., Fiszilewicz M., Le Coz Y., Morel M.T., Szylit O., 1978. Influence of the axenic state on the utilization of carbohydrates by chicken. 6th int. Symp. Gnotobiotics, June 1978, Ulm/Donau, Fed. Rep. Germany.

Bewa H., Charlet-Lery G., Szylit O., 1979. Rôle de la microflore digestive et de la structure cristalline de l'amidon dans la digestion et l'utilisation des régimes chez le poulet : étude de tubercules tropicaux. Ann. Nutr. Aliment., 33, 213-231.

Champ M., Szylit O., Gallant D.J., 1981. The influence of microflora on the breakdown of maize starch granules in the digestive tract of chicken. Poult. Sci., 60, 179-187. 
Eastwood M.A., 1973. Physiology of bile acids in the ileum and colon. Scot. Med. J., $18,142-145$.

Erbersdobler H., Riedel G., 1972. Bestimmung der Aminosäurenverdaulichkeit bei Keimfrei Konventionell gehaltenen Küken. Arch. Geflïgelkd., 36, 218-222.

Gordon H.A., 1960. The germ-free animal. Am. J. Dig. Dis., 5, 841-867.

Ivorec-Szylit O., Raibaud P., Schellenberg P., 1973. The breakdown of starch at different levels in the digestive tract of the axenic, gnotoxenic and holoxenic chicken. In : Germ-free research : biological effect of gnotobiotic environments, Heneghan J.B. ed., New York and London, Academic Press, 225-231.

Hill F.W., Anderson D.L., 1958. Comparison of metabolizable energy and productive energy determination with growing chicks. J. Nutr., 64, 587-603.

Kussaibati R., Guillaume J., Leclerce B., Lafont J.P., 1982. Effects of the intestinal microflora and added bile salts on the metabolizable energy and digestibility of saturated fats in the chicken. Arch. Geflügelkd., 46, 42-46.

Kussaibati R., Leclerco B., Guillaume J., 1982. Effets du calcium, du magnésium et des sels biliaires sur l'énergie métabolisable apparente et la digestibilité apparente des lipides, de l'amidon et des protéines chez le poulet en croissance. Ann. Zootech. (in press).

Lepkovsky S., Wagner M., Furuta F., Ozone K., Koike T., 1964. The proteases, amylase and lipase of the intestinal contents of germ-free and conventional chickens. Poult. Sci., 43, 722-726.

Miller W.S., 1967. Protein utilization in germ-free and conventional chicks given a purified diet. Proc. Nutr. Soc., 26, X (abst.).

Parsons C.M., Potter L.M., Browns R.D., Wilking T.D., Bliss B.A., 1982. Microbial contribution to dry matter and amino acid content of poultry excreta. Poult. Sci., 61, 925-932.

Rolls B.A., Turvey A., Coates M.E., 1978. The influence of the gut microflora and of dietary fibre on epithelial cell migration in the chick intestine. Br. J. Nutr., 39, 91-98.

SALTER D.N., FULFORD R.J., 1974. The influence of the gut microflora on the digestion of dietary and endogenous proteins : studies of the amino acid composition of the excreta of germ-free and conventional chicks. Br. J. Nutr., 32, 625-637.

Szylit O., Charlet G., 1981. Energy and protein retention in holoxenic, axenic and gnotoxenic chickens monoassociated with lactobacillus spp. Br. Poult. Sci., 22, 305-315.

Terpstra K., de Hart N., 1974. The estimation of urinary nitrogen and faecal nitrogen in poultry excreta. Z. Tierphysiol. Tierernähr. Futtermittelkd., 32, 306-320. 